\title{
Research on Policy Incentive System to Strengthen the Construction of Professional Aged-car Service Team
}

\author{
Dapeng Cong \\ Yantai Nanshan University \\ Yantai, Shandong, China 265713
}

\author{
Shengqun Wang \\ Yantai Nanshan University \\ Yantai, Shandong, China 265713
}

\author{
Yan Gao \\ Yantai Nanshan University \\ Yantai, Shandong, China 265713
}

\begin{abstract}
This paper analyzes the local government in researching and developing the policy incentive mechanism of pension services industry to design a suitable one for the local government. It is purposed to coordinate the pension service work and local government economic and social development to adjust with the improvement of security level of pension service and promote the sustained and healthy development of the pension service industry in this region and also to increase continually the happiness index of old people for their healthy and happy ageing life. The paper focuses on the problem how the local government to realize the supervision and encouragement mechanism of the pension services industry in fair competition.
\end{abstract}

Keywords—pension services; team construction; policy incentives; mechanism

\section{INTRODUCTION}

Whether an industry can develop in a healthy and orderly way, team construction is an important condition. The team construction referred in the text includes practitioner team, operator team, and investor team, and among them the practitioner team counts. The text elaborates on exploring the policy incentives of team construction for the practitioners engaged in pension service. Due to low social status, low income, risky job content, bigger mobility of pension service staff and their low specialty, it causes a substantial lack of pension service practitioner. In Sep. 2013, The Opinions on Speeding up the Development of the Pension Services Industry, issued by the State Council, points out that the talent cultivating policy should be completed. This indicates that, from national to local, fostering a pension service team with professionalization and stability has become a key work of pension service industry. This paper holds the idea that the local government can start from the following several aspects to do well in cultivating teams.

\section{POLICY InCENTIVES MECHANISM OF THE CONSTRUCTION OF THE PROFESSIONALIZATION ON PRACTITIONER}

With the development of society, the quantity of older adults living alone and disabled elders continues to increase, which leads to the growing demands of social pension service. The pension services have a broad market prospect, which embodies in creating many jobs for society due to its energetic development and in satisfying the meets of diversified and increasing-greatly elder market. In order to make the pension services on the path of becoming younger, more competent, special and professional, the matters related to the ratio of pension services staff are defined by the health condition and the self-care ability of the elderly as well as the signed service agreements abroad. But at present in the domestic, the issue on personnel compounding ratio has not been clearly defined. Because the development of pension institutions in our country is still in the beginning stage and uneven in various regions, local government should consider the practical situation of local area to set feasible standards for personnel compounding ratio of the pension services and to stipulate that institutes should sign a labor contract with staff according to the law.

Whereas for the general provisions of the pension institution practitioners, local government leads and in coordination with Civil Administration Department, Personal Guaranty, Financial Department, Education Department etc. and other relevant competent departments to handle from the following two aspects: Course contents include many majors such as Geriatrics, Rehabilitation, Nursing, Nutriology, Psychology and Social Work etc., meanwhile tuition wavier and pecuniary aid should be given to the students who register for examination pension services major, to ensure the supply of pension services talent cultivating and the stability of the team in the region. For the sake of giving play to the role in promoting employment of social pension services and sparing no effort to solve the prominent problem existing in team construction of pension services, it is suggested to depend on 
the nursing home which has advanced management in the region and then appropriately introduce the advanced operation management and nursing service training materials from home and abroad; it also should use the local vocational and technical education platform to build the pension services training base and implement the classified training then working with the certificate. Training fee can be handled by financial agency, retirement organization or trained individuals. The government should study and formulate mechanism of pension services to inject professional personnel of social work and try to create social jobs in pension services. In addition, unify local colleges and universities to cultivate oriented professional staff in gerontological nursing, operation management in mechanism of pension services and studies on the aging psychology or other aspects.

\section{Policy InCENTIVES MeChANISM OF THE StABLE CONSTRUCTION OF THE PRACTITIONER TEAM}

Private old-age institution-services practitioners differ from the professional staff under the public institutions' establishment, and they will post after going through the market training. However, this part of the training fee usually paid by the private old-age institution itself. On account of the particularity of the client groups in pension services industry and the bigger mobility of the staff, institutions have to bear the payment on training fee over and over again. In order to promote the development of pension institutions in the region, the expenditure of institutions should be reduced.

\section{RESEARCH ON THE INCENTIVE MECHANISM OF PROMOTING THE WiLlingNESS OF THE PRACTITIONER TO WORK}

The mobility and instability of the service personnel in pension services institutions are the important factors to impede the development of China's pension services industry all the time. The local government must pay attention to the issue how to strengthen the stability of team engaged in pension industry and how to promote the pension services industry to develop in a healthy and orderly way.

The article believes that the low income and low social identity resulted from low social status mainly cause the mobility of the service staff. To solve this problem, it is important to not only cultivate the professional and sound pension services team but also learn the advanced cases from home and abroad. It also counts to direct the media to increased publicity so as to let all levels of society know the importance of the pension services industry as well as its importance to all society. Nowadays the profession of the pension services team also should be known to improve self and social identity of the pension services staff.

\section{THE RESEARCH ON INCENTIVE MECHANISM OF THE TEAM CONSTRUCTION OF INVESTOR AND OPERATOR}

The team construction referred in the text content includes not only practitioner team and but also the operator and investor team at the same time, especially the operator of the pension institution. The important condition to ensure the local government pension services industry develops in a sustainable way is to create the sophisticated professional running team and extend investors' scale and the quantity of operator. Local government can take turns to develop the staff training courses and arrange the professional training in pension institution overall in the region. At the same time, this text believes that local government can implement the subsidy policy for the training in pension services industry from two aspects: the pension services staff and the pension institution.

\section{THE RESEARCH ON INCENTIVE MECHANISM OF IMPROVING THE COMPENSATION PACKAGE}

Local government can promote pension institutions to improve the welfare of employees through various policies about cutting the running costs of the institutions. On one hand, government can state clearly in the policy that pension institution should increase compensation if it enjoys the political fiscal subsidy or apply for the funds of services industry; on the other hand, government can relax the entrance policy of this industry and introduce the market and competition mechanism so that pension institution has to increase compensation in order to retain the staff who have the professionalism and rich experience. Local government implements the wage subsidy for the pension services staff and then implements the social premium subsidy about town enterprise staff and workers for them who have formally signed a labor contract with pension institutions and also are engaged in it now. For the people of employment difficulties with local household registration in the pension services industry but having signed a labor contract, they can enjoy the wage subsidy referred to the local minimum wage standard. Meanwhile, local government should give appropriate training fee subsidy to the pension services staff. For the employees who have signed a formal contract with the pension institutions or other non-government organizations and are occupied in it now, local civil affairs department can grant the one-time training subsidy after they participate in the training of professional skills in pension services and obtain its job certificate; if with an intermediate occupational skills certificate, the subsidies will increased. For the training of personnel belonging to the re-employment, after being recognized by the local civil administration department and personal guaranty department, they can enjoy not only the free training but also the subsidy of the training. The local civil administration department and personal guaranty department also can study how to get through the "public" and "private" channel to make pension institution staff flow freely as well as enjoy the same social insurance to ensure the stability of the staff in private pension institutions. Local government should bring the talents in pension services into the intra-regional qualified personnel development program and formulate its salary standard to strive to improve the staff' salaries and welfare, and it also should improve the work environment of pension services. Government also can adopt the preferential policies such as check-in subsidies for the staff and encourage the vocational College to recommend its professional students to the pension institutions, while the staffs who make outstanding contributions to pension services should be commended and rewarded. The age levels of old people who are sent to the pension institutions are different, so their social needs differ too. Especially the empty nester without being 
accompanied by their children, while they are in good physical condition so what they need is the general care; for the elders who need special care such as in bad physical condition, they should be taken care of by the staffs who have some certain medical knowledge and even with a medical licensing. Local government should set up the corresponding professional qualification standards according to the different needs of pension institutions, and meanwhile it also should encourage various profession training institutions to carry out the vocational skills training for the personnel in this services industry, then to issue the corresponding qualification certificate to the passer. The ranking of various pension institutions can take the professional qualification personnel's accounting data as its judgment criteria. For example, all the pension institution personnel must obtain the job certificate. People who obtain the junior certificate or the middle and senior job certificate can be provided with professional level evaluation system of professional social workers and make a scientific definition to the their positions and duties in home care services. Local government also should strengthen to absorb and train the professional talents and improve the staff's occupational ethics education as well as the team's overall quality. Government should consummate the mechanism of primary pension services and carry out the system of professional qualification examination of old-age nursing staff in order to make the staff all post with certificates.

\section{THE RESEARCH ON INCENTIVE MECHANISM OF RESERVE OF TALENTS MECHANISM}

Pension Industry is a labor intensive industry and it needs a lot of professional talent resources. However, at present China is facing with the lake of talent resources in pension aspects. It is a matter of the utmost urgency to speed up promoting to cultivate the professional talents in pension services. The article thinks that the pension service staffs in the market today are lack in profession and most of them are migrant workers or age of them is 40 to 50 . The main reason this team lack the stability is short of long-term cognition of pension service industry and enthusiasm for the industry. It is suggested that the line ministries of local government should set major and professional course content related to pension service in kinds of technical colleges and universities of this region to provide the ways of external service as well as some more professional knowledge and ideas such as method of persuasion to common psychological problems in the elderly, basic knowledge of medicine, correct method of first aid and excellent cases and developing trend of the pension services at home and abroad etc. Pension services industry, this huge potential market, badly needs a large number of professional practitioners. This not only can provide fresh blood for the pension services industry timely but also ensure the team's professional and stability. Geographical conditions of the local government are preferred and also have the corresponding institutions of resources, such as Qunyi Vocational and Technical School located in Maqiao Town. The government should take financial subsidies and other measures to encourage vocational colleges to offer courses related to pension service industry.

\section{REFERENCES}

[1] Luo Haiping, Ling Dan. Countermeasures and Suggestions on Accelerating the Development of China's Pension Services Industry. [J].Special Zone Economy. 2013 (09).

[2] Tian Fei, Yu Yifan. Brief Analysis of Chinese Pension Estate. [J] Shanghai Urban Planning. 2013 (03).

[3] Wang Fuying, Pan Tingting. Measures on Establishing and Completing Industrial System of Shenyang Pension Services. [J]. Manager. 2013 (13).

[4] Ban Xiaona, Ge Su. Method and Revelation of Developing the Pension Services Industry Abroad [J]. Journal of Dalian Maritime University (Social Science Edition). 2013 (03).

[5] Ni Jiangwei. Feasibility Analysis on Private Capital Entering into Pension Services Industry of Guangzhou City. [J]. Times Finance. 2013 (14).

[6] Liu Xiaomei. The Situation and Path Selection Faced with Social Pension Services of China. [J]. Population Study. 2012 (05).

[7] Zhang Benbo. The Economic and Social Consequence Analysis and Policy Choice of Aging of Population of China. [J]. Macroeconomic Study. 2002 (03).

[8] Yang Yanying. Adjust the Policy of Finance and Taxation Promote the Development of Pension Services Industry in Our Country. [J]. Macroeconomic Management. 2013 (06).

[9] Lv Zhixin. Realistic Needs and Future Development of Pension Services Industry in Our Country[J]. Chinese Hospital Building and Equipment. 2013 (08). 